\title{
EGYETEMI HALLGATÓK MENTÁLIS TÉRKÉPEI MAGYARORSZÁGRÓL
}

\author{
(Mental maps of Hungary - as the university students see it) \\ KISS JÁNOS - BAJMÓCY PÉTER
}

A mental map-ek módszerérōl

A nyugati társadalomföldrajz utóbbi húsz-harminc évének egyik legfontosabb új irányzata a behaviorista geográfia. A hatvanas évek közepén az Egyesült Államokban megjelent iskola képviselöi alapjában szakítottak a hagyományos társadalomföldrajz térszemléletével, amely a teret az emberek cselekedeteinek kereteként szolgáló változatlan, abszolút képződményként tekintette. Már a behaviorista geográfia elsỏ mủvei (Lynch 1960) abból a fẹttevésbỏl indultak ki, hogy az emberek térbeli viselkedését nem a tér objektív szerkezete, hanem annak az észlelés során keletkezett szubjektív képzete határozza meg. Nem aszerint cselekszünk tehát, amilyen a tér a maga valóságában, hanem amilyennek látjuk.

A behaviorista "forradalom" (Cséfalvay 1990) rảirányította a geográfusok figyelmét azoknak a "fejünkben élő" képzeteknek a vizsgálatára, amelyek valójában meghatározzák az egyes emberek, illetve társadalmi csoportok térbeli cselekedeteit. Az ilyen jellegủ kutatások egyik leggyakrabban használt módszere a mentális térképek vizsgálata, amely a valós környezet szubjektív tudati leképeződésének folyamatáról nyújt más eszközökkel fel nem deríthetó információkat.

A vizsgálat kulcsproblémája: a tudati képződmények "előhívása" a fejekből alapvetően módszertani jellegủ. Megoldására ez idáig két, egymástól lényegesen eltéró kísérleti eljárás terjedt el (Solomon 1978). Az egyik az ún. "rajzos módszer". Ez eredetileg Kevin Lynch-tól származik, aki három amerikai nagyváros: Boston, Los Angeles és Jersey City mentális térképeit rajzoltatta meg kísérleti személyekkel, majd összehasonlította az így készült térképeket valósághủségük szerint. Lynch után sorra keletkeztek a különböző városok mentális térképeiröl készített dolgozatok és ezek elemzése során derült ki, hogy a térképek "minösége" nemcsak a vảros "olvashatóságától" fưgg, hanem a rajzolók társadalmi helyzetétől is. E módszer lényege tehát az, hogy a kísérleti személyek maguk rajzolnak térképeket, és a kutató ezeket hasonlítja össze, illetve összegzi. A rajzokat a legtöbben városok mentális térképeinek vizsgálatára használják, de az eljárást többen sikerrel alkalmazták már országos kutatásokban is (Downs-Stea 1977). Kísérletünkben mi is ezt a módszert követtük.

A második gyakran használt eljárást nevezhetjük "rang-módszernek" is. Ennek ötlete Peter Gouldtól származik (Gould-White 1968). Lényege, hogy a kutató maga sorolja fel azokat az objektumokat, amelyekre kíváncsi, és a kísérletben részt vevó személynek annyi a feladata, hogy egy megadott tulajdonság szempontjából rendezze ezeket az objektumokat. A klasszikus kérdés ebben az esetben: "Hol laknál legszivesebben, ha 
szabad választásod lenne?" - majd a válaszként adott rangsorokból a kutató készíti el a megfelelö térképeket.

A mentális térképekkel kapcsolatos kutatások alapvető jelentősége, hogy általuk a társadalmi térfolyamatok más módszerekkel nem, vagy csak bizonytalanul feltárható mozzanatairól kaphatunk részletes információkat. Ezáltal új szempontokkal egészithetók ki a társadalomföldrajz egyéb, "hagyományos" módszerei alkalmazása révén kapott adatok egy egész sor, gyakorlati szempontból is nagy jelentöségú probléma esetében, mint pld. a szuburbanizáció, a földrajzi identitás, a települési kapcsolatok, illetve a lakóhelyi szegregáció kutatása, valamint a városmarketing terén is.

\section{A vizsgálat célkitüzése, a megvalósítás lépései}

Magyarországon ez idáig viszonylag kevesen foglalkoztak mentális térképek készittetésével, illetve vizsgálatával (Cséfalvay-Fischer 1990, Timár 1994), s e kísérletek egyaránt várostérképek rajzolására, az egyes városainkról éló tudati képek vizsgálatára irányultak. Legalább ennyire fontos tudni azonban azt is, hogy az egész országról milyen kép él az emberekben, az egyes országrészek és települések hogyan tükrözódnek a tudatunkban.

A kutatás fö kérdései három egyszerúen megfogalmazható, ám annál nehezebben kutatható probléma elemzésére irányultak. Elöször is arra voltunk kíváncsiak, hogy milyen térbeli képződményeket tartalmaznak az egyetemisták fejében élö térképek Magyarországról: mennyire egyeznek meg ezek a valóságos térképekkel, és miben különböznek azoktól. A második fö kérdés az volt, hogy milyen tényezök játszanak szerepet a kognitív térképek kialakításában: mennyiben határozzák meg ezt objektive létezỏ térfolyamatok, és hogyan nyilvánul meg a - társadalmi, vagy pszichológiai eredetủ szubjektív tényezők hatása? Végül, elméleti és gyakorlati szempontból is kulcsfontosságú volt az a kérdés, hogy milyen új, más módon fel nem ismerhető következtetések tehetők a módszer alkalmazása révén?

Magyarország mentális térképeinek vizsgálatára a rajzos módszer kismértékben módosított változata tủnt legalkalmasabbnak. $\mathrm{Az}$ általunk választott eljárás során a kísérleti személyek, a szegedi József Attila Tudományegyetem I-II. éves hallgatói, egy Magyarország határait tartalmazó A/4-es papírlapot kaptak. A kiadott feladat lényege a következö volt: "Jelöljön be és nevezzen meg ezen a térképvázlaton 1.0 perc alatt annyi földrajzi helyet, amennyit csak tud!" Felhívtuk a válaszadók figyelmét, hogy természeti földrajzi objektumokat lehetöleg ne írjanak be, mert ezek kívül esnek a vizsgálat körén. Ha szükségesnek érzik, megjelölhetnek persze ilyen fogalmakat (hegyek, folyók, tavak, stb.) is, de ezeket az értékelésnél nem vesszük figyelembe. A hallgatók tisztában voltak azzal is, hogy a szépség és a pontosság kevésbé számít, annál fontosabb viszont az egyértelmúség: azaz, hogy amely objektumokat bejelölik, azokat feltétlenül és egyértelmủen nevezzék is meg.

A rajzolási feladat után néhány, a térképek elemzése szempontjából hasznosnak érzett háttérváltozót is felvettünk (évfolyam és a szak, származás és lakóhely, az apa, illetve az anya legmagasabb iskolai végzettsége). - Összesen 208 szegedi egyetemista (91 férfi és 117 nỏ) töltötte ki a kérdőiveket, közülük 109 földrajz szakos, valamint 99 további nemföldrajzos hallgató, a természettudományi, a bölcsészettudományi, és a jogi karról. 
A mental map-ek módszerének külföldi alkalmazói is gyakran választották mintának egyetemi hallgatók csoportját. Fontos, hogy társadalmilag, illetve képzettség szempontjából viszonylag homogén csoportot alkotnak. Így számos társadalmi kủlönbség hatását kívül tarthattuk a vizsgálat körén, s a kevesebb hatótényezỏ jobban elkülöníthető volt. Az egyetemisták emellett vállalkozó kedvüek, s nagyobb csoportokban könnyen elérhetőek, ami az adatfelvételt jelentősen meggyorsítja és egyszerǔsíti. Végül, bár valamennyi kérdőívet Szegeden töltötték ki, mégis az ország egész területének lakói megtalálhatók az egyetemista válaszadók között.

A kitöltött adatlapok elemzése meglehetősen időigényes feladat volt annak ellenére, hogy a nagy mennyiségủ adat elemzését számítógép segítségével végeztük. A leghosszadalmasabb feladat a térképi jelölések kódolása volt, mivel településszinten, és az egyes bejelölések pontosságára vonatkozóan is matematikailag értelmezhetó és értékelhetó információkhoz szerettünk volna jutni. Minden egyes említett térképi elem egy 1 és 10 közötti kódot kapott. A pontszerü adatokat 1-essel kódoltuk abban az esetben, ha a hely valódi középpontjától számítva egy kb. $30 \mathrm{~km}$ átmérőjü kőrön belülre jelölte be óket a válaszadó. Ettől szigorúbban csak két esetben jártunk el: ha, az adott település határmenti, volt; másrészt akkor, ha a $30 \mathrm{~km}$-es átmérőjú körön belül fekvő helyek egymáshoz viszonyított helyzete hibás volt.

A hibásan bejelöltnek ítélt elemeket annak alapján kódoltuk, hogy milyen irányban tértek el valóságos térképi helyüktól. Így azok az objektumok, amelyeket alapvetóen Észak felé "tolt el" a válaszadó, 2-es kódot kaptak; az ÉK-i fóirányú eltérésnek a 3-as, a K-nek a 4-es, a DK-nek az 5-ös, a D-nek a 6-os, a DNy-nak a 7-es, a Ny-nak a 8-as, az ÉNy-nak pedig a 9-es kódot feleltettük meg. A durván hibás, teljesen rossz helyre rajzolt objektumok 10-es kódot kaptak. - Úgy ítéltük meg, hogy a vizsgálat szempontjából lényeges információt az eltérések iránya hordoz. Feltételeztủk, hogy ha egy a térképi elemet említöi rendszeresen és tendenciózusan egy adott irányba tolnak el valódi helyzetéhez képest, akkor ez a térbeli észleléseinket torzító valamilyen társadalmi eredetủ hatásnak az erèdménye lehet, s így ezek elemzése támpontokat nyújthat a mentális térképek alakításában szerepet játszó szociológiai tényezőkrỏl is.

A vizsgálatnak számos korlátja is van.

A pszichológiai korlátok közé tartozik, hogy egyszerübb az olyan objektumokat bejelölni, amelyeknek jól behatárolható helye van, amelyeket például az országhatár orientál. Másrészt a vizsgálat egyetemistákra terjedt $\mathrm{ki}$, akik speciális életkori és foglalkozási csoportot alkotnak, valamint eddigi iskolai végzettségük és jelenlegi tanulmányaik kővetkeztében ismeretszintjük valószínủleg magasabb, mint más társadalmi csoporté.

A korlátok újabb típusa származik abból, hogy a kísérletben csak szegedi egyetemisták vettek részt, így Szeged és környéke természetesen túlreprezentált. A minta összetétele ugyan szinte tökéletesen kifejezi a szegedi József Attila Tudományegyetem vonzáskörzetét, viszont semmiképpen sem felel meg az országos területi reprezentáció követelményének. Az állandó lakóhelyek regionális megoszlásának aránytalanságaiból eredő torzítást azonban jelentósen sikerült csökkenteni olymódon, hogy az adatok elemzésénél általában figyelmen kívül hagytuk a válaszadó sajảt lakóhelyének megyéjéböl említett objektumokat. Így a kutatás eredményeként az országról kirajzolódó kép számos elemében általánosítható vélekedéseket tükröz.

Az a tény, hogy a mintában sok földrajzos volt, korlát, de ugyanakkor speciális értelmezési lehetőség is. Vizsgálható ezáltal ugyanis az, hogy bizonyos speciális területi 
érdeklődés, illetve az ennek következtében kapott iskolai, vagy más többlettudás hogyan módosítja a Magyarországról alkotott képet. A minta így nem volt reprezentatív a JATE hallgatóira nézve sem. A különböző karok hallgatói térképeinek összehasonlításánál ugyanakkor kiderült, hogy közöttük sem az említési gyakoriság, sem más szempont szerint jelentős kủlönbség nincsen.

Korlátot jelentett az is, hogy csak az említések tényét vettük figyelembe, az ezekhez tartozó értéktartalmat, szubjektív viszonyulást, valamint a bejelölések sorrendjét sem; holott valószínúleg ezek is jelzik a településekről, tájakról alkotott szubjektív képek különbségeit. Mindezen korlátok mellett azonban a vizsgálat értékelhető eredményeket hozott: szignifikánsnak tekinthető összefüggések adódtak, és számos markáns tendencia egyértelmủen kirajzolódni látszik a 208 kérdőiv elemzésébỏl.

\section{A szegedi egyetemisták Magyarország - képe}

\section{Ami a térképeken szerepel - és ami nem}

A kutatás alapkérdése az volt: milyen globális kép rajzolódik ki az országról a térképvázlatok alapján? A 208 kérdóíven összesen 10013 egyértelmủen azonosítható, objektumot jelöltek meg a válaszadók. (Megjegyzendö ugyanakkor, hogy nagyon sokan annak ellenére berajzolták a Dunát, illetve a Tiszát és a Balatont is, hogy tudatában voltak ezek a felmérés tárgyán kívül esnek. Ez arra utal, hogy az ország területének szubjektív tagolásában fontos tájékozódási irányt jelöl ki a három közismert természetes tájelem.) $\mathrm{Az}$ egyes válaszadók átlagosan 48 értékelhető említést tettek, ezen belül a földrajz szakosok természetesen valamivel többet, a többi egyetemista pedig valamivel kevesebbet. Az említések száma meglehetősen nagy szóródást mutat: a legkevesebb bejelölést tartalmazó térképen 9 elem szerepelt, a "rekorder" adatlapon pedig 136; a szórás a teljes minta esetében 19,6 volt.

$\mathrm{Az}$ említett objektumok valamivel több, mint felét (57\%-át) fogadtuk el pontos bejelölésként a korábban említett eljárásnak megfelelöen. A várakozásoknak megfelelỏen a földrajz szakosok térképei voltak pontosabbak: az ő esetükben a megjelölt helyeknek 63 , míg a többieknél átlagosan 49\%-a szerepelt a valódi helyének megfelelöen. A szórás itt is viszonylag nagy volt: $17 \%$. Az "abszolút rossz" bejelölések (10-esek) kis aránya arra utal, hogy azokról a helyekről, amelyeknek bejelölésére vállalkoztak a válaszadók, volt valamilyen, többé-kevésbé pontos információjuk. Az a tény viszont, hogy minden második-harmadik válasz érzékelhetöen pontatlan volt, jelzi azt is, hogy ezek az információk gyakran hiányosak, a válaszadók térbeli képzeteit számos torzító hatás is formálja.

A jelentős szórási értékek arra utalnak, hogy a térképi ismeretek mennyisége és pontossága egyaránt meglehetősen ingadozó az egyetemisták csoportján belül is. A különbségek magyarázatát keresve a nem bizonyult a legjelentősebbnek mind az említési gyakoriság, mind pedig a bejelölési pontosság eltéréseinek tekintetében. A férfi válaszadók térképein általában több, és pontosabban megjelölt elem szerepelt. A kapcsolat ugyan korántsem függvényszerű, és a minta is kicsi, feltevésként azonban megkockáztatható: lehetséges, hogy a térkép részletesebb és helyesebb ismerete inkább maszkulin, mint feminin tulajdonság? A többi háttérváltozó közül egyedül a családi háttér, ezen belül is inkább az anya iskolai végzettsége mutatott minimális (pozitív irányú) összefüggést az említési gyakorisággal. A társadalmi státus kiválasztott mutatói csak 
kismértékben voltak alkalmasak a térképi ismeretek különbségeinek magyarázatára. Az egyetem relatíve magas szinten egységesíti az ismereteket. Elképzelhető, hogy más csoportoknál a társadalmi helyzet differenciáló hatása jóval erósebb lehet. - Végül: szignifikáns, bár nem túlságosan erős összefùggés $(r=+0.30)$ mutatkozott az említések száma, és a pontos bejelölések aránya között. Aki tehát több adatot jelölt be, viszonylag pontosabban is tette azt.

Az említések összesen 975 földrajzi név között oszlottak meg, amelyeknek zöme településnév volt. 188 város és 643 község mellett kereken 100 településrész és 44 egyéb név (zömmel megye- és tájnév) fordult elö. Mindezek mellett a válaszadók kb. 15\%-a több-kevesebb egyéb, általa fontosnak tartott térbeli elemet is megemlített (leggyakrabban út- és vasútvonalakat, illetve olyan helyeket, mint pl. "puszta", "Suzuki-gyár", "McDonalds", "vadaspark" stb.), amellyel a maga számára azonosította az ország egyes pontjait. Ezeket azonban szórványos jellegük miatt a további elemzésekben figyelmen kívül hagytuk.

A településállomány mintegy $27 \%$-át említették legalább egy alkalommal, ezeknek tủlnyomó része azonban csak egy-két térképen szerepel. 5\%-nál nagyobb arányban már csak 150, 10\%-os említési gyakoriság fölött már csak $90,30 \%$ fölött $45,50 \%$ fölött pedig 30 hely fordult elö. A vizsgálat adatszerüen is igazolta, hogy a városok szerepe meghatározó a "fejekben élö" térképek kialakításában. Míg az említett neveknek 20\%-a volt városnév, addig az összes említésnek 79\%-a jutott a városokra. (Ebben a tekintetben a válaszadók részmintái között nem voltak számottevő különbségek.) Ennek az adatnak a tudatában válik különösen érdekessé, hogy melyek azok a városok, amelyek esetlegesen, 1-2 alkalommal fordulnak csak elö. Róluk ugyanis valószínűsíthető, hogy közvetlen környékük lakóin kívül nem jelennek meg az emberek tudatában, s így nem játszanak szerepet az országról, illetve régiójukról a közvéleményben kialakuló kép formálásában.

Az ország 200 városi jogállású települése közül 12 nem fordult eló egyszer sem a térképeken. Hozzájuk sorolható ugyanakkor az a további 34 település is, amelyeket saját megyéjük lakóit nem számítva legfeljebb 1\%-nyi válaszadó említett. Ezek többsége kis lélekszámú, hiányos városi alapfunkciókkal rendelkező, jórészt az utóbbi időszakban várossá nyilvánított település. Néhány jelentősebb népességủ (Budaörs, Balmazújváros, Gyomaendród, Tiszavasvári, Edelény) vagy komoly városi múlttal rendelkező település (Hajdúnánás, Túrkeve) is ide sorolódott. Területi elhelyezkedésüket vizsgálva szembeötlö, hogy - a budapesti agglomerációba olvadó két-három kisváros kivételével - zömmel az ország elmaradott, válság sújtotta régióiban találhatók, míg az ÉNy-i régió öt megyéjében (Gyór-Moson-Sopron, Komárom-Esztergom, Vas, Veszprém, Zala) csak 3 ilyen város akad. Már ezek az információk is arra engednek következtetni, hogy az egyetemisták, tudatából is kikapcsolódnak a hátrányos helyzetủ területek, s magatartásuk térbeli viszonyítási pontjai inkább a fejlett, vagy perspektivikus vidékekhez kötődnek.

Az ország településeinek, illetve régióinak másik, jelentős csoportját alkotják azok, amelyeket a nem-helybéliek közül is jelentős arányban megjelöltek. A 1. ábrán az elöforduló fỏldrajzi nevek közül azokat tüntettem fel, amelyek a "más-megyeiek" kérdőíveinek legalább 5\%-án felbukkantak. Történeti-néprajzi egységek, vagy akár megyenevek is csak elvétve fordulnak elö a térképeken, s ez azt mutatja, hogy a regionális identitás megkülönböztetỏ értéke igen kicsi az egyetemisták számára. Az ország inkább elkülönült pontok halmaza számukra, s nincs erös táji-tradicionális kötődésük. 


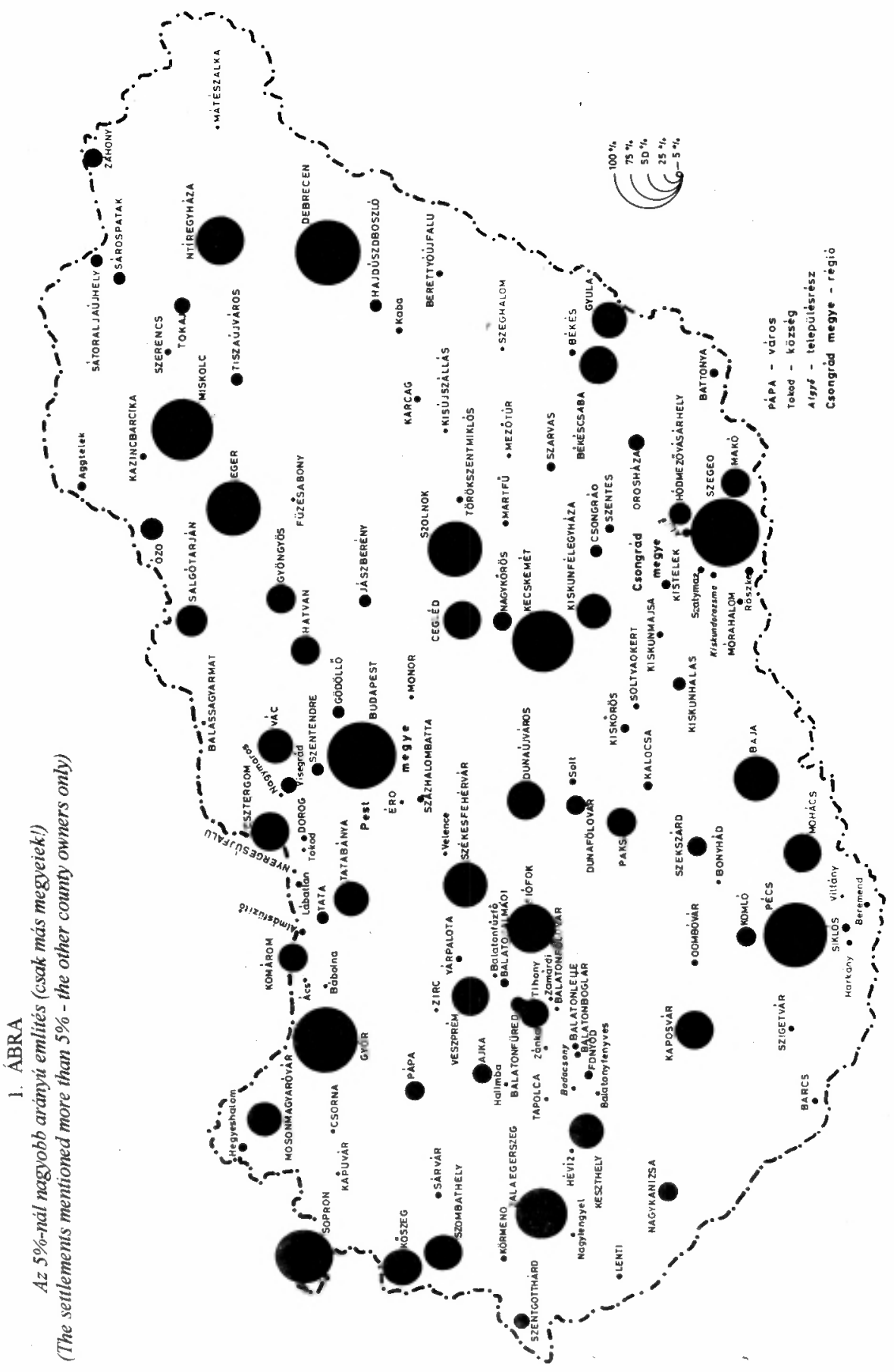


A megye szerepe mégis tetten érhető a mental map-ekben: saját megyeszékhelyét ugyanis 2-3 kivétellel valamennyi válaszadó feltüntette, és az összes említés 29\%-át a megyeszékhelyek teszik ki (Budapesttel együtt számítva).

\section{A mentális térképeket kialakitó főbb tényezók}

Az ország egyes területein a gyakran említett települések csoportosulása figyelhető meg, míg máshol nagy kiterjedésű, összefüggő "fehér foltok" vannak. Ezek a különbségek számos eltérő tényezőcsoport eredményeként alakultak ki, amelyek elemzése az országról létező kognitív térképek különbségeinek okaira is utal egyben.

Az első ilyen faktort a településhálózat sajátosságai, illetve a településhierarchia hatásai jelentik. A települések megjelölésének aránya sok esetben nagyjából megfelel a településhierarchiában elfoglalt helynek, illetve a népességi rangsornak. (Budapestet és Szegedet minden válaszadó megemlitette) A gyakorisági sor első hét helyéböl hat a legnagyobb regionális centrumoké, s a megyeszékhelyek a két legkisebb lélekszámú megyeszékhely kivételével az első 30 között szerepelnek. Igaz az a tétel, hogy a kisebb városokat községeket lényegesen kevesebben említik.

A hierarchia hatása nemcsak országosan, hanem a megyei szinten is meghatározó ( 1 . táblázat). A megyéken belül három kivétellel (Somogy, Tolna, Komárom) a megyeszékhelyek állnak az élen az emlitési gyakoriságokat tekintve, s e három kivétel is valamelyik egyéb faktor nagy erejú hatásának köszönhető. Azokon a területeken, ahol megyeszékhely említéseinek nagy az aránya (Nógrád, Szabolcs, Hajdú, Szolnok megyék) más településeket szinte csak az adott megye lakói emlitettek; a többiek számára viszont kizárólag a székhelytelepülés jeleníti meg e területeket. Nem tekinthető véletlennek, hogy épp a jórészt elmaradott, válság sújtotta régiókat ismerik legkevésbé a más vidékeken lakók.

Ahol a megyeszékhely említéseinek viszonylag alacsony a részaránya, az egyéb tényezők hatásának tulajdonitható. Somogy és Veszprém megye esetében az idegenforgalomnak, amely a térképezés újabb tipikus faktora. A Balaton-part településeinek ismertségét a 1 . ábrán mérhetjük: Siófok, Keszthely és Tihany kiugró említésszáma mellett még 11 település említései haladták meg az 5\%-os arányt. Néhány "szavazatot" pedig a part szinte valamennyi települése elért. A község-említések gyakorisági "versenyének" dobogós helyein is három idegenforgalmi jellegü falu szerepel: Tihany után Visegrád, majd Aggtelek következik, de számos egyéb település (Harkány, Hévíz, Velence, Tokaj, Sárospatak) jó "szereplésében", valamint a Bükk és a Mátra üdülőterületeinek gyakori felbukkanásában is valószínúleg ez a tényezó játssza a fó szerepet.

Az idegenforgalom jelentős szerepét a mental map-ek kialakításában kétféle, egymással összefüggő hatással magyarázhatjuk. Az egyik a személyes élményeké, amelyek a hazai nevezetességek meglátogatásához kötődnek. Szükséges azonban hangsúlyozni, hogy a köztudatba bekerülö helyek körének meghatározásában a marketing, a reklám, illetve hordozói szerepe kiemelkedő. A közvélemény figyelmét ezek az eszközök irảnyítják bizonyos látványosságokra, s általuk településekre, régiókra (Cséfalvay 1990.) 


\section{TÁBLÁZAT}

A megyék leggyakrabban emlitett négy településének néhány jellemzö adata (Some main data of the four settlements by counties, mentioned the more often)

\begin{tabular}{|c|c|c|c|c|c|}
\hline Településnév & 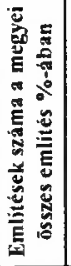 & 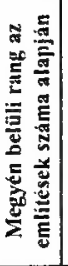 & 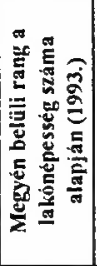 & 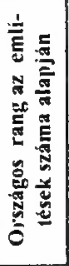 & 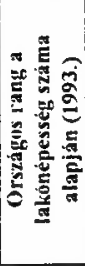 \\
\hline \multicolumn{6}{|l|}{ Baranya } \\
\hline Pécs & 38,1 & 1. & 1. & 3. & 5. \\
\hline Mohảcs & 22,1 & 2. & 3. & 20. & 62. \\
\hline Komló & 11,7 & 3. & 2. & 42. & 43. \\
\hline Siklós & 5,6 & 4. & 5. & 71. & 132. \\
\hline \multicolumn{6}{|l|}{ Bacs-Kiskun } \\
\hline Kecskemét & 25,6 & 1. & 1. & 6. & 9. \\
\hline Baja & 18,4 & 2. & 2. & 14. & 25. \\
\hline Kiskunfélegyháza & 15,0 & 3. & 3. & 26 & 33. \\
\hline Kiskunhalas & 6,0 & 4. & 4. & 57. & 39. \\
\hline \multicolumn{6}{|l|}{ Békés } \\
\hline Békéscsaba & 26,2 & 1. & 1. & 16. & 14. \\
\hline Gyula & 21,8 & 2. & 2. & 30. & 30. \\
\hline Oroshàza & 12,3 & 3. & 3. & 48. & 34. \\
\hline Szarvas & 7,3 & 4. & 5. & 64. & 71. \\
\hline \multicolumn{6}{|l|}{ Borsod-A-Z } \\
\hline Miskolc & 29,0 & 1. & 1. & 7. & 3. \\
\hline Ozd & 11,4 & 2. & 2. & 38. & 24. \\
\hline Tokaj & 7,7 & 3. & 18. & 51. & 269. \\
\hline Sarospatak & 7,4 & 4. & 7. & 53. & 88. \\
\hline \multicolumn{6}{|l|}{ Csongrád } \\
\hline Szeged & 31,3 & 1. & 1. & I. & 4. \\
\hline Makó & 12,3 & 2. & 4. & 36. & 46. \\
\hline Hódmezỏvásárhely & 10,5 & 3. & 2. & 39. & 21. \\
\hline Csongrád & 5,8 & 4 & 5. & 62. & 65. \\
\hline \multicolumn{6}{|l|}{ Fejér } \\
\hline Székesfehérvár & 39,9 & 1. & l. & 15 & 8. \\
\hline Dunaújvaros & 35,9 & 2. & 2. & 17. & 18. \\
\hline Velence & 4,3 & 3. & 15. & 109. & 302. \\
\hline Mór & 2,8 & 4. & 3. & 151 & 92. \\
\hline \multicolumn{6}{|l|}{ Gyōr-ML-S. } \\
\hline Gyơr & 33,5 & 1. & 1. & 4 & 6. \\
\hline Sopron & 30,1 & 2. & 2. & 8. & 19. \\
\hline Mosonmagyaróvár & 18,5 & 3. & 3. & 25. & 38. \\
\hline Hegyeshalom & 5,5 & 4. & 10. & 66. & 373. \\
\hline \multicolumn{6}{|l|}{ Hajdú-Bihar } \\
\hline Debrecen & 58,2 & 1. & 1. & 5. & 2. \\
\hline Hajdúszoboszló & 12,6 & 2. & 3. & 59. & 50. \\
\hline Berettyóúfalu & 6,5 & 3. & 8. & 83. & 81. \\
\hline Kaba & 4,9 & 4. & 17. & 101. & 213. \\
\hline \multicolumn{6}{|l|}{\begin{tabular}{|l} 
Heves \\
\end{tabular}} \\
\hline Eget & 34,0 & 1. & 1. & 10. & 16. \\
\hline Gyongyos & 17,8 & 2. & 2. & 34. & 29. \\
\hline Hatvan & 16,9 & 3. & 3. & 37. & 49. \\
\hline Fizzesabony & 2,6 & 4. & 5. & 123. & 169. \\
\hline \multicolumn{6}{|l|}{ Jász-N.-Sz. } \\
\hline Szolnok & 47,4 & 1. & 1. & 9. & 11. \\
\hline Jászberény & 12,6 & 2. & 2. & 56. & 42. \\
\hline Martfü & 5,7 & 3. & 14. & 87. & 173. \\
\hline Karcag & 5,4 & 4. & 4. & 92. & 53. \\
\hline
\end{tabular}

\begin{tabular}{|c|c|c|c|c|c|}
\hline Településnév & 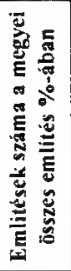 & 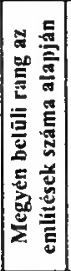 & 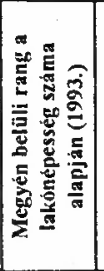 & 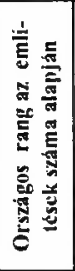 & 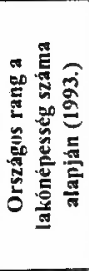 \\
\hline \multicolumn{6}{|c|}{ Komárom-Esztergom } \\
\hline Esztergom & 23,1 & 1. & 2. & 22. & 40. \\
\hline Tatabanya & 21,6 & 2. & 1. & $2 \%$ & 12. \\
\hline Komárom & 16,9 & 3. & 5. & 35. & 64. \\
\hline Tata & 9,0 & 4. & 3. & 55. & 48. \\
\hline \multicolumn{6}{|l|}{ Nógrád } \\
\hline Salgótarján & 58,3 & 1. & 1. & 31. & 22. \\
\hline Balassagyarmat & 9,3 & 2. & 2. & 110 & 72 . \\
\hline Pásztó & 4,0 & 3. & 4. & 203. & 134. \\
\hline Lpolvtamóc & 3,3 & 4. & 92. & 223. & 2006 \\
\hline \multicolumn{6}{|l|}{ Pest } \\
\hline Cegléd & 18,5 & 1. & 2. & 23. & 27. \\
\hline Vác & 16,8 & 2. & 3. & 29. & 31. \\
\hline \begin{tabular}{|l|} 
Nagukỏros \\
\end{tabular} & 9,5 & 3. & 6. & 46. & 45. \\
\hline Visegrád & 7,9 & 4. & 121. & 52. & 857. \\
\hline \multicolumn{6}{|l|}{ Somogy } \\
\hline Siofok & 30,9 & 1. & 2. & $I 2$. & 52. \\
\hline Kaposvár & 23,7 & 2. & 1. & 24 & 13. \\
\hline Fonyód & 6.8 & 3. & 7. & $6 ?$ & 256. \\
\hline Barcs & 4,3 & 4. & 5. & 86 & 110. \\
\hline \multicolumn{6}{|l|}{ Szabolcs-Sz-B. } \\
\hline Nyiregyháza & 48,6 & 1. & 1. & 13. & 7. \\
\hline Zahony & 20,6 & 2. & 18. & 43. & 271. \\
\hline Mátészalka & 4,9 & 3. & 2. & 108. & 67. \\
\hline Kisvárda & 3,1 & 4. & 3. & 150. & 75. \\
\hline \multicolumn{6}{|l|}{$\begin{array}{r}\text { Tolna } \\
\end{array}$} \\
\hline Paks & 29,4 & 1. & 3. & 32. & 59. \\
\hline Drunafoldvar & 21,8 & 2. & 7. & 40. & 163. \\
\hline Szekszárd & 20,1 & 3. & 1. & 44. & 26. \\
\hline Dombóvár & 5,5 & 4. & 2. & 101. & 58. \\
\hline \multicolumn{6}{|l|}{ Vas } \\
\hline \begin{tabular}{|l} 
Szombathely \\
\end{tabular} & 30,9 & 1. & 1. & 18. & 10. \\
\hline Köszeg & 30,4 & 2. & 5. & 21. & 111 \\
\hline Szentgotthárd & 12,8 & 3. & 6. & 50. & 155. \\
\hline Kormend & 5,1 & 4. & 3. & 89. & 109. \\
\hline \multicolumn{6}{|l|}{ Veszprem } \\
\hline Veszprém & 19,3 & 1. & 1. & 19. & 15. \\
\hline Tihany & 14,1 & 2. & 34. & 33. & 1029. \\
\hline Ajka & 10,2 & 3. & 3. & 41. & 35 \\
\hline Pápa & 9,5 & 4. & 2. & 45. & 32. \\
\hline \multicolumn{6}{|l|}{ Zala } \\
\hline Zalaegerszeg & 35,9 & 1. & 1. & II. & 17. \\
\hline Keszthely & 25,2 & 2. & 3. & 28. & 54. \\
\hline Nagykanizsa & 13,5 & 3. & 2. & 4 & 20. \\
\hline Lenli & 5,2 & 4. & 4. & 81. & 152. \\
\hline
\end{tabular}


Vizsgálatunk eredményei arra utalnak, hogy a Magyarországra vonatkozó földrajzi ismeretek a turisztikai "ipar" által manipuláltak, visszatükrözik annak szlogenjeit, valamint a sajtó elöítéleteit is. Ennek kihasználása persze lehetőségeket is kínál, hiszen a médiákból visszaköszönö idegenforgalmi helyszínek - ha nem egyértelmüen negatív szöveg környezetben említődnek meg - tágabb környezetük image-ének formálásában egyértelmủen pozitív szerepet játszanak.

Az összesített térképeken nem ábrázolható, de az egyes kérdőíveket szemlélve az elsők között tủnik szembe a következő faktor: a származás, lakóhely, a "szükebb pátria" szerepe a mental map-ek formálásában. A válaszadók nagyobbik részénél a lakóhely körül a megjelölt pontok sürüsödése tapasztalható, $\mathrm{s}$ köztük az átlagosnál jóval nagyobb a kisvárosok, illetve a községek szerepe. Azok az "átlagos" falvak, amelyeket csak egyszerkétszer említettek meg, zömmel az ilyen, lakóhely körüli "bolyokban" kerültek rá a térképekre.

A származás jelentőségének statisztikai megítélésére jobb híján a megyéket használtuk fel területi egységként, ám ez a viszonylag durva közelítés is számos érdekes tanulsággal szolgált. Az egyes válaszolók említéseiknek átlagosan 14\%-ában valamilyen, saját megyéjük területén található objektumot neveztek meg, s ez kb. háromszor akkora érték, mint a többi megyék átlaga. (Ez az arány nem függött a megyék nagyságától.) Miként mindenki megnevezte az ország székhelyét, Budapestet, két-három kivétellel mindenki bejelölte saját megyeszékhelyét is. A megye többi városa is jóval gyakrabban szerepel, mint a többieknél. Saját megyéjükön belül pontosabban is jelölték be az egyes helyeket a válaszadók, ami szintén arra utal, hogy a közvetlen személyes tapasztalaton alapuló térképi ismeretek tartósabbak, pontosabbak, és a mentális térképek kialakitásában meghatározóbbak, mint a külsődlegesen szerzett tudás. A lakóhely e hangsúlyos szerepéböl is kitünik ugyanakkor a magyar lakosság területi mobilitásának alacsony szintje, amely - mint erre a városföldrajzi munkák rámutatnak (Cséfalvay 1990) - csak töredéke a fejlett nyugati országok hasonló adatainak. Válaszadóink $75 \%$-a ma is ugyanabban a településben lakik, ahová 19-20 évvel ezelótt született.

Meglehetősen erős faktornak bizonyult a határok (illetve a határátkelöhelyek) szerepe. Ez, az adatfelvétel módjából is következhet. Ám az egyes határszakaszok és -átkelők között olyan tendenciózus különbségek is tapasztalhatók, amelyek véleményünk szerint nem vezethetök vissza az adatfelvételi eljárás hibáira.

A városok közül Sopron, Szentgotthárd, Köszeg, Gyula, Komárom, Barcs és Záhony említése esetében játszhat valamelyes szerepet a határátkelö-funkció. A viszonylag gyakran említett, és föleg határvárosként ismert Záhonytól eltekintve egyértelmünek látszik a nyugati, illetve a déli határszakasz kitüntetett jelentősége. A községek közül a 4. leggyakrabban említett település Hegyeshalom, amely napjainkban is "a" nyugati határ megtestesitője. Hozzá mérhető még Röszke említésszáma, majd Kelebia, Tompa, Hercegszántó, Nagylak, Rajka, Szob is közel hasonló (4-5\% körüli) gyakorisággal következik. A leggyakrabban említett településrészek (Szeged városrészei mellett) valamennyien határátkelök: Rábafüzes, Parassapuszta, illetve Somoskőújfalu. Megállapítható tehát, hogy a határok erösen élnek az egyetemisták tudatában, és térbeli cselekvéseik egyik viszonyitási alapjaként szolgálnak. Itt is feltủnik azonban, hogy csak a nyugati-északi határszakasz térképi helyeit jelölték meg pontosan a válaszadók: a fó tájékozódási irányt ez jelentette számukra.

A megjelölt térképi helyek következő - immáron ötödik - jelentős típusát a közlekedési útvonalak, a viszonylag gyakran bejárt nagy távolságú térpályák (Mészáros 1994) és az 
ezek mentén elhelyezkedő települések alkotják. A JATE hallgatóinak nagyobb csoportjai által használt hazautazási útvonalak (föként vasúti) tömegközlekedési fövonalakhoz és megállóhelyeikhez kötődnek. E tényezőnek köszönhetően szerepelnek gyakran a 140.sz. Szeged-Budapest vasúti fővonalon fekvő települések (pl. Kiskundorozsma, Szatymaz, Kistelek, Kiskunfélegyháza, Nagykőrös, Cegléd, Monor), valamint a 100.sz. (CeglédSzolnok-Debrecen-Nyíregyháza-Záhony) és az 1.sz. (Budapest-Tatabánya-Györ-Hegyeshalom) vasútvonal kisebb állomásai is. Az autóbuszvonalak közül a Szeged-Kiskunhalas (Kiskunmajsa)-Dunaföldvár (Közép-Dunántúl); a Szeged-Baja-Pécs (Dél-Dunántúl); illetve a Szeged-Orosháza-Békéscsaba-Szeghalom-Berettyóújfalu irányok szerepe tekinthető jelentősnek. Néhány település relatíve nagy említésszámát egyértelmủen közlekedési csomópont-szerepe okozza (Solt, Dunaföldvár, Cegléd, Füzesabony).

A kognitív térképek szerkesztésének stratégiáiról szólva a szakirodalom (Cséfalvay 1994) is felhívta a figyelmet arra, hogy az útvonal-módszer az egyik leggyakrabban alkalmazott térképezési eljárás. Ezt a mi kutatásunk is igazolta. Ugyanakkor az útvonalmódszer a centrum köré szerveződő térképezéssel kombinálódik, hiszen Celldömölk körül számos kistelepülés is felkerült a térképre. (A harmadik tipikus módszernek a megadott keretet "egyenletesen kitöltő" eljárás bizonyult.)

A I. ábrán található nagyobb "fehér foltok" is jórészt kapcsolatba hozhatók a közlekedéssel. Kisebbik részük ugyan megfelelỏen kiépített közlekedési hálózattal rendelkezik, ám az egyetemisták Szegedre irányuló térpályáira merólegesek lévén, említési gyakoriságuk kicsi (Budapest-Pécs vasútvonal). Általában rossz közlekedési helyzetủ, forgalmi árnyékban fekvö "belsỏ perifériák" ezek, amelyek egyéb szempontokból is közismerten hátrányos helyzetünek tekinthetők. A két legnagyobb kiterjedésủ ilyen terület a Közép-Tisza-vidék, Somogy megye túlnyomó része a Dráva-vidékkel és az Ormánsággal (továbbá Cserehát, Bodrogköz, Szatmár-Bereg, Bihar).

$\mathrm{Ez}$ a tény is azt bizonyítja, hogy az említési gyakoriság (és a bejelölések pontossága is) szoros összefüggésben van az adott telepullés vagy régió "közmegítélésével", image-ével. Az egyetemisták többségében csak a "jó helyekröl" alakulnak ki határozott térbeli képzetek, ezek orientálják térbeli cselekvéseiket, választásaikat; ezzel szemben az általuk fejletlennek, lemaradónak tekintett régiókat ösztönösen kikapcsolják tudatukból, tóvolítják mindennapi gondolkodásukból. Megfordítva az összefüggést: a mental map-ek készítése körültekintő elemzés esetén már az említési arányok és pontosság vizsgálata által információkat kínál arról, hogy miként osztják fel, miként értékelik tudatukban az orszạg régióit az emberek.

A hierarchiában elfoglalt pozíciójukhoz képest nagyobb gyakorisággal említett települések zöme is a "jó hely"-ként számon tartott régiókban található - ezzel szemben az "üres", jórészt csak a megyeszékhelyek által képviselt régiók rossz szubjektív megitélésủek. Úgy tünik, a régiók külsó megitélése szempontjából alapvetö fontosságú, hogy karakteresen megjelenjenek a "külvilágban" élök tudatában. Ehhez képest másodlagos, hogy pozitív, vagy negatív a megítélés: a rossz image-ét meg lehet változtatni, akit viszont nem érzékelnek, annak problémái sem léteznek számukra márpedig ezen régiók többsége csak külső segítséggel reménykedhet a felzárkózásban. A területi egyenlötlenségek újratermelődésének egyik, eddig kellően nem ismert, de fontos szubjektív eleme deríthetö fel a kognitív térképek elemzése által. A települések, a régiók image-e pedig a mentális térképeket kialakító önálló faktornak tekinthető.

Hogyan néz ki tehát az ország térképe az egyes területeknek a mental map-ek alapján feltételezhető megítélését tekintve? A kirajzolódó kép tendenciája nem meglepő: az észak- 
és nyugat-dunántúli régió megyéi a legjobb megítélést tükrözö csoportba kerültek. (A válaszadók 56\%-a a hat alföldi megyében lakik !) - Heves megye megitélése jobb, mint azt a fejlettsége és gazdasági mutatói alapján várhatnánk, $s$ különösen kedvezönek tünik ez a kép annak figyelembevételével, hogy valamennyi szomszédja legalább két kategóriával alatta marad. Ez a kedvezö image - amelyet csak részben magyarázhatunk a megye idegenforgalmi vonzerejével - komoly eröforrást jelenthet a későbbiekben a hevesiek számára. - Ellentétes irányú meglepetést kelthet viszont Fejér megye relatíve rossz szereplése. Ennek egyik oka, hogy Székesfehérváron és Dunaújvároson kivül nincs más "karakteres arculatú" települése, ez a két város adja a megyei összes említés 76\%-át. Az is valószínünek látszik, hogy a közvéleményben még nem tudatosult Székesfehérvárnak és vidékének az utóbbi években elért gazdasági sikere, látványos fejlödése.

Feltűnő az ország középső részén található homogén közepes értékeket mutató zóna, amelyböl Baranya és Csongrád megye ugrik csak ki egy kissé (elöbbi helyzetét közlekedési és idegenforgalmi pozíciói, utóbbiét a felmérés helyszíne magyarázzák). Hozzájuk hasonló még Borsod megye értéke is, amelynek számos települése került az utóbbi időben a közérdeklődés homlokterébe. Borsodnak köszönhetően törik meg így kissé a - Heves kivételével - egyértelmủen negatív képet mutató Északkelet-Alföld és Észak-Magyarország egysége.

A mentális térképek ilyen szempontú elemzése összességében arra utal, hogy az egyetemisták Magyarország-képe egyértelmüen differenciált, tudatukban határozottan létezik egyfajta kelet-nyugati lejtô:: a viszonylag dinamikus Északnyugat-Magyarország mellett egy széles, átmeneti "átlagos" zónát, és egy leszakadó Északkelet-Magyarországot èrzékelnek.

Megfigyelésünket az eddig felsoroltakon kívül további adatok is alátámasztják. A kilenc dunántúli megyéból hat a gyakoribb említéseket tartalmazó két kategóriába került - míg a másik tíz megyéböl csak kettőről mondható el ugyanez. A, leggyakrabban említett 135 településnek 53\%-a dunántúli, míg az ország területének és vidéki lakosságának is csak 39\%-a. Az azonos nagyságrendü északnyugat-dunántúli és északkelet-magyarországi települések említési arányai között gyakran nagyságrendi különbségek vannak (az egyaránt 30 ezres lélekszámú Mosonmagyaróvár és Hajdúböszörmény esetében 52,3\% illetve 2,5\% a mutató értéke). Különösen feltünő a térkép üressége a Tiszántúlon. A nem-földrajz szakosok mental map-jeinek többségéröl elmondható, hogy - az egy Debrecenen kívül "semmi sincs" kb. a Miskolc-Békéscsaba vonaltól K-re.

A tudati képnek érdekes jellemzői azok a karakterisztikus hibák is, amelyeket bizonyos telepulések bejelölésekor elkövettek a válaszadók. Több esetben megfigyelhetö volt, hogy a hasonló jellegünek látott, hasonlóan értékelt települések térben is egymáshoz közel kerültek, egy szük térképi területen zsúfolódtak össze. Így például jellemző módon az §szaknyugat-magyarországi városokat (Györ, Sopron, Mosonmagyaróvár, Szombathely, köszeg) együttesen gyakran Györ-Moson-Sopron megye északi-középső kétharmadán helyezték el, mig Salgótarjánt ill. egész Nógrád megyét a borsodi iparvidék területén \$zerepeltették a válaszadók. A legjellemzöbb példa azonban talán mégis Záhony esete. Az \$9, nem Szabolcs megyei emlitő 73\%-a ugyanis DK-re, az ország legkeletibb határpontjának közelébe helyezte. A többség (a földrajz szakosok is!) szó szerint az ország "keleti kapujának" tartják a várost. Egyébként Szabolcs és Borsod megye többi településénél is a Kelet felé való eltolás (távolítás) volt a leggyakoribb hiba.

Mit lehet kezdeni a mentális térkép-elemzések eredményeivel? Milyen 'gyakorlati haszon \$zármazhat e felmérésekböl az érintett területek számára? - teszik fel gyakran a kérdést. A 
válasz a mi kutatásunkkal kapcsolatban talán az átlagosnál könnyebben megadható: az egyes régiók, települések saját magukra vonatkozó információinak teljességéhez, reális önképük kialakításához nagyon fontos lehet a mások által róluk alkotott kép reális megrajzolása, amihez a mental map-ek elemzése nagyban hozzájárulhat. A telepulés- és területfejlesztési politikának ezen közítéletek, és az általuk (is) kialakított érdekviszonyok között kell mủködnie; az önerős térségfejlesztés egyik legfontosabb eszközének tekinthető régiómarketing stratégiája pedig nem alapulhat bizonytalan, vagy hamis önképen. Ha a pontosan felmért image változtatására készül jól kidolgozott program, akkor ez sok más, objektív tényeket (pl. infrastruktúra, foglalkoztatottság stb.) megváltoztató akciónál nagyobb eredményeket hozhat. Egyrészt olcsóbb lehet a mentális térképek mögött meghúzódó kedvezőtlen tudati kép változtatása; másrészt a fejlódést nem elég megvalósitani: a kedvező hatások érvényesülését az segítheti elö igazán, ha a pozitiv változások tényére fel is hivják a külvilág figyelmét.

Néhány egyéb érdekes szabályszerüség is kimutatható. Ilyen a "közelség törvénye" (Cséfalvay 1990). Valamilyen tudati vagy társadalmi hatás következtében az egymáshoz hasonlónak vélt településeket a válaszadók gyakran a tényleges távolságuknál közelebb helyezték egymáshoz. Érzékletes példája ennek, hogy egyes megyékben a feltuintetett városokat a megyeszékhelyhez közelítették a válaszadók. Ennek megfelelóen Csongrád megyében Makót, Mórahalmot, Szentest Szeged felé tolták leggyakrabban; Pest megyében pedig szinte valamennyi jelentősebb települést (Cegléd, Monor, Nagykőrös, Vác) Budapesthez "húzták".

Más jellegủ a hasonlóság törvényének érvényesülése. Ennek értelmében a valamilyen meghatározó tartalmi jelleg alapján hasonlónak gondolt települések leggyakrabban együtt fordulnak elö. Így a három bakonyi bauxitbányász község (Szőc, Nyirád és Halimba), vagy a három Duna-parti ipari település (Almásfüzitő, Lábatlan és Nyergesújfalu) szinte csak együtt szerepeltek. Elöfordult a hasonló hangzású és jelentéstartalmú nevek (Szombathely-Székesfehérvár; Herend-Hollóháza, Kaposvár és Dombóvár) felcserélése is a térképen.

Ebbe a gondolatkörbe tartozó, de az előzőeknél jóval lényegesebb összefüggés végül az, hogy megfigyelésủnk szerint az adott földrajzi név hangalakja befolyásolhatja említési gyakoriságát. A könnyen megjegyezhető, karakterisztikus nevet viselő helységek sokkal nagyobb gyakorisággal szerepeltek, mint a "semmitmondó"; "jellegtelen" helynevek. Így Zalaegerszeget háromszor annyian jelölték, mint az ugyanakkora Nagykanizsát; vagy Battonyát kétszer annyian, mint a közelében fekvő Mezőkovácsházát és Mezỏhegyest együttvéve; Ajkát majdnem háromszor annyian, mint a hasonló jellegủ és jelentőségü Várpalotát. A Balaton-parti telepulések közül pedig a "Balaton"-kezdetủeket jóval kisebb arányban említették, mint egyedi nevü szomszédaikat (Balatonfüredet csak kétharmadarányban jelölték a szomszédos Tihanyhoz képest).

Vizsgálatunk során arra is kísérletet tettünk, hogy megállapítsuk az iskolai (földrajz)oktatás hatását a kognitív térképek kialakítására. Ennek érdekében a válaszadókat két csoportból állítottuk össze: az egyetemista "átlagot" reprezentálók mellett olyan, I.-II. évfolyamos földrajz szakos hallgatókból, akik az egyetemen még nem tanultak Magyarországról, így térképeik csak a közoktatás hatását tükrözhették. Elsősorban az említett helyek struktúrájának eltéréseire voltunk kíváncsiak.

A legmarkánsabb különbség az említések megoszlásában a települések funkcionális típusait tekintve mutatkozott. A földrajzosoknál jól elkülöníthető, jelentős említésszámmal rendelkező csoportot alkottak azok az ipari- és bányásztelepulések, amelyek a többieknél 
nem, vagy jóval kisebb arányban fordultak csak elő (Nagylengyel 13-0; Halimba 12-0; Szerencs 19-1; Dorog 26-2; Martfü 22-3; Kazincbarcika 21-3; Komló 49-14; Ajka 35-19; Salgótarján 62-30) - A földrajzosok ezek mellett jóval gyakrabban említettek neveket az elmaradottabb, rosszabb image-ủ régiókból (Nyírbátor 10-0; Kisvárda 8-2; Mátészalka 144; Szeghalom 14-4; Balassagyarmat 13-4)

A nem-földrajzosok esetében viszont jóval erösebbnek mutatkozott a településhierarchia, valamint a személyes tapasztalatokból eredỏ tényezök: a lakóhely, az útvonalak, és néhány kiránduló- illetve fürdöhely (Leányfalu, Zalakaros, Orfü, Lillafưred, Mátraháza) szerepe. Térképeiken megjelentek a megyék. Az 5-15\% közötti említési gyakoriságok azonban arra utalnak, hogy az emberek tőbbsége számára a megyenevek nem alkalmasak a földrajzi helyek azonosítására.

Vizsgálatunk tehát azt mutatja, hogy a nem-földrajzosok Magyarországgal kapcsolatos térbeli képzeteinek kialakitásában az iskolai oktatásnak vajmi kevés szerepe van. Ezt a tényt érdemes rögzíteni, mert a társadalom széles csoportjainak kognitív térképei inkább az övékéhez hasonlítanak, mint szakmabeliekéhez - csak jóval alacsonyabb szinten. Úgy tủnik, hogy az iskolában sulykolt térképi ismeretek ma már több szempontból korszerütlenek, és a középiskola befejezése után 2-3 évvel - megerősítés híján - ki is hullanak az emlékezetböl.

A laikusban, de akár a módszert közelebbről nem ismerő szakmabéliben is könnyen felmerülhet a kérdés: megéri-e ez a módszer a befektetett energiát? Valóságosak-e a kapott eredmények? Nem túl nagy-e a véletlenek szerepe? Valóban lehet vele valamire jutni? - A kapott eredmények e téren önmagukért beszélnek. Kiderült, hogy a módszer révén nyert adatokból matematikai-statisztikai eszközökkel is elemezhetö, geográfiailag jól értelmezhető összefüggéseket lehet megállapítani. Az ábrákon nem csoportosultak volna olyan rendezetten az információk; a számítások eredményeként nem adódtak volna ilyen szignifikáns összefüggések; végül nem lehetett volna ezeket az eredményeket ilyen egyértelmủen hozzárendelni számos, a társadalomföldrajz által vizsgált objektíve létező jelenséghez, folyamathoz (településhierarchia, területi egyenlötlenségek, funkcionális különbségek, térpálya-kutatás, település image-kutatás, a régiómarketing problémái), ha véletlen tényezök nagyban befolyásolták volna a válaszokat.

Mindezek tükrében a vizsgálat leglényegesebb új eredményeinek a következők tekinthetök:

- Az eddigi településszintủ alkalmazások után - hazai viszonylatban elöször - országos hatókörủ kutatásban is sikerült bizonyítani a módszer használhatóságát.

- Egyértelmüen bizonyossá vált, hogy az emberek fejében erösen differenciált kép él az ország különböző vidékeiröl, és sikerült rámutatni ennek néhány lehetséges összetevőjére.

- Sikerült elkülöníteni az országról az egyetemisták fejében élő térképek kialakításának néhány jellemzö tényezöjét.

- Végül: bebizonyosodott, hogy ennek a módszernek az alkalmazása révén a társadalomföldrajz képes lehet számos más társadalomtudomány (pszichológia, szociálpszichológia, szociológia) eredményeinek integrálására. 


\section{Irodalom}

Cséfalvay Z. (1990) Térképek a fejünkben. Akadémiai Kiadó, Budapest.

Cséfalvay Z. -Fischer, W. (1990) Cigányzene és lakáshiány - sztereotipiák és a valóság ellentéte a Budapestképben. Földrajzi Értesitö 1-4. 207-220. o.

Cséfalvay Z. (1994) A modern társadalomfóldrajz kézikönyve. Ikva Könyvkiadó Kft., Budapest. 366. o.

Downs, R. -Stea, D. (1977) Maps in Minds: Reflections on Cognitive Mapping. Harper \& Row, New York.

Gould, P. -White, R. (1968) The mental maps of british school-leavers. Regional Studies 2. 161-182. o.

Lynch, K. (1960) The lmage of the City. MIT-Press, Cambridge/Mass.

Mészáros Rezsö (1994) A település térbelisége. JATEPress Szeged.

Solomon, L. (1978) Mental mapping: a classroom strategy. Journal of Geography, February.

Timár Judit (1994) "Mental map" alkalmazásának lehetőségei a térpályák kutatásában egy alföldi vizsgálat tapasztalatai. Az "alföldi út" kérdôjelei. Békéscsaba. 312-318. o.

\section{Abstract}

What can we do, with the results of a mental-map analysis? What is the measurable benefit for a certain settlement?

The answer we can give is clearer, more intelligible than in an average research. The analysis of the mental-maps can help the settlement, or a small region to make they character complete, to inform them about the opinions of the outside people, to make a realistic self-picture. The regional and settlement policy or the regional marketing, the development strategies functioning in a realistic space, in a space of the common verdicts and interests. The development srategy cannot based on an uncertain or a false picture.

If the project based on a certain image analysis, completed with some objectiv facts (e.g. infrastructure, employment activity) the projects can be very efficient, make better results. It would be cheaper to change the mental views on the one hand, but they must draw the positive tendentions to the people's attention. This process can help to enforce the favourable effects. 